\title{
Pastoral livelihoods of the Fulani on the Jos Plateau of Nigeria
}

\author{
Ayodele O Majekodunmi ${ }^{*}$, Akinyemi Fajinmi ${ }^{2}$, Charles Dongkum², Alexandra P M Shaw ${ }^{1}$ and Susan C Welburn ${ }^{1}$
}

\begin{abstract}
The Jos Plateau is an important cattle-producing area in Nigeria, with a high concentration of pastoral Fulani. In recent decades, pastoralist studies have focused on arid and semi-arid areas, with few based in the sub-humid zones, such as the Jos Plateau. There have been significant socio-economic and agricultural changes in this area over time which makes it necessary to assess current pastoral livelihood strategies. A pastoral livelihood analysis of 66 individual households/herds across 30 villages was conducted, using participatory methods and structured questionnaires. The majority of pastoral households are in the middle or better off wealth categories and only a few are poor in terms of livestock holdings. However, the majority are poor in terms of land holdings. Livestock sales remain the major source of income, but only $30 \%$ of households rely on this as their sole source of income. Sale of crops, milk and off-farm activities contributed income in other households. Comparison with previous livestock productivity levels on the Jos Plateau shows that natural resource conflict has increased, with negative effects on productivity, although vulnerability to shocks has decreased over the years. Overall productivity has decreased and calving rates were particularly low. The pastoral Fulani community is relatively well-off, compared to similar populations across West Africa. However, the high proportion of wealth concentrated in livestock and large numbers of land-poor households indicate that there is still a degree of vulnerability to the risks of drought/dry season, disease and conflict in pastoral livelihoods in the area.
\end{abstract}

Keywords: Pastoral; Fulani; Sustainable livelihoods; Cattle; Livestock productivity; Nigeria; Jos Plateau

\section{Background}

Small-scale livestock production is a major contributor to the economies of sub-Saharan countries, especially for the rural populations. It also plays an essential role in food production, and the protein provided by livestock products is an important component of this. There are 120 million pastoralists worldwide, 50 million of these in sub-Saharan Africa where they constitute 12\% of the rural population (Rass 2006). The Fulani are the primary pastoral group in Nigeria with a population of approximately 15.3 million. The Fulani first settled on the Jos Plateau around 1910, attracted by the low levels of disease and abundant grasslands, and are present in large numbers till today (Blench 2004).

\footnotetext{
* Correspondence: ayo.majekodunmi@ed.ac.uk

'Division of Pathway Medicine and Centre for Infectious Diseases, School of Biomedical Sciences, College of Medicine and Veterinary Medicine, The University of Edinburgh, Chancellor's Building, 49 Little France Crescent, Edinburgh EH16 4SB, UK

Full list of author information is available at the end of the article
}

The ability of pastoralists to fulfil their role as food producers is directly dependent on the viability of their livelihoods and the factors affecting their livelihood strategies. The livelihoods of pastoral people depend on three things: first, access to assets such as land, livestock, pasture, water, animal health services, community networks, markets, credit and education; second, the environment in which these assets are combined for production and consumption, specifically the political, organisational and institutional infrastructure within which they operate, which affects their ability to use these assets to achieve positive livelihood outcomes; and third, the dynamic context of risks (human and animal disease, marginalisation, drought, civil conflict and competition for natural resources) and seasonal and continuous trends that affect assets and their environment and determine the vulnerability of livelihoods (Rass 2006; Eldis.org 2010). Vulnerability is a measure of the lack of resilience to risks and seasonal and long-term trends. Therefore, it is not only an important feature of poverty but also a potential cause.

\section{它 Springer}


Vulnerability is closely linked to asset ownership - the more assets people have, the less vulnerable they are. The greater the erosion of assets, the greater the level of vulnerability - poor herders are more likely to end up with an unviable herd size than wealthier herders, even when they lose the same relative amount of livestock (Rass 2006).

The literature on pastoral livelihoods and customs focuses on pastoralists located in the arid/semi-arid zones but less emphasis on those located in the sub-humid zones such as the Fulani of the Jos Plateau (Catley 2000). Recent changes in population, land use, socioeconomic climate and tsetse and trypanosomiasis risk on the Jos Plateau have had significant effects on pastoral livelihoods on the Plateau. Little information is available on the current state of pastoral livelihoods or the drivers for the epidemiology of trypanosomiasis in this area. Therefore, a longitudinal research project was carried out between 2007 and 2008 to provide a comprehensive summary of the epidemiology of bovine trypanosomiasis on the Jos Plateau; determine which social, economic, ecological and cultural factors influence animal health and disease control by herders; provide an overview of current pastoral livelihoods including quantitative analysis of animal productivity and profitability to herders and examine the effects of recent changes in socio-economic and security factors on pastoral livelihood strategies. Results on the epidemiology of trypanosomiasis and social factors affecting it have been published in Majekodunmi et al. (2013a, b). This paper is concerned with livestock productivity and the current state of pastoral livelihoods on the Jos Plateau.

\section{Study area}

The Jos Plateau (Figure 1) in north central Nigeria covers an area of $8,000 \mathrm{~km}^{2}$ at an average altitude of $1,280 \mathrm{~m}$. It consists of younger granite of volcanic origin, and the terrain is characterised by numerous rocky, flattopped hills and crater lakes. The Jos Plateau, formerly open savannah woodland but now mostly grassland, is a highly populated, intensively cultivated area. It was

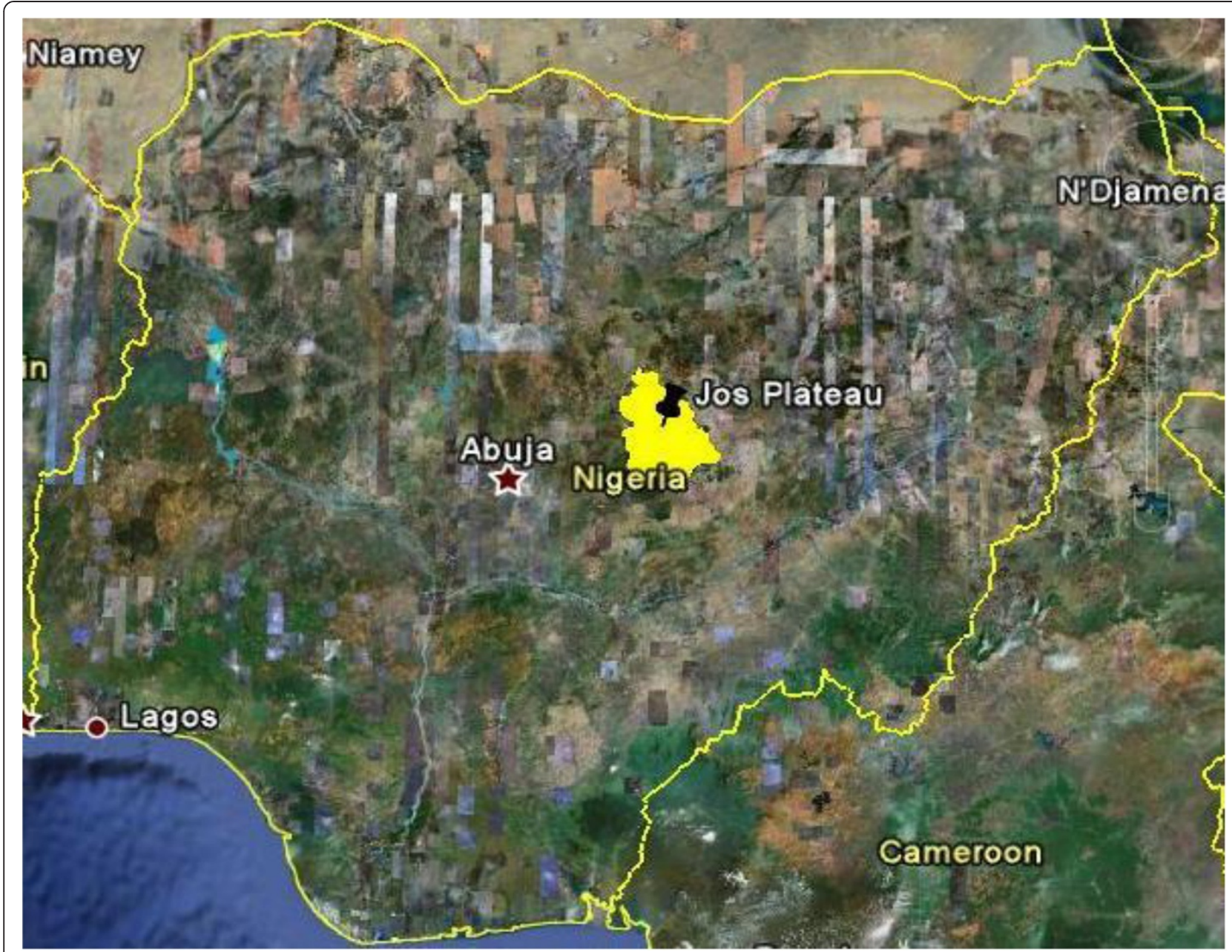

Figure 1 Jos Plateau. 
historically free of tsetse flies and trypanosomiasis. The absence of trypanosomiasis and abundant pasture attracted large numbers of cattle-keeping pastoralists. The area now holds over a million cattle and plays an important role in the national/regional cattle industry. However, beginning in 1982, there have been increasing reports of tsetse flies and African animal trypanosomiasis (AAT) on the Plateau (Majekodunmi et al. 2013a).

The Plateau shows high ethno-linguistic diversity, without any of the large-scale political units that characterise Yoruba- or Hausaland. In pre-colonial times, the Plateau was populated by a great variety of small ethnic groups living in hamlets with a complex clan organisation and ritual kingship systems speaking an assortment of 'Plateau' languages and a few Chadic languages related to Hausa. Therefore, no single language or people were dominant, although the largest ethnic groups were (and still are) the Birom, Ngas and Tarok (Gunn 1953; Blench 2004). These tribes lived mostly in the natural fortresses provided by the hills, and the central plain of the Plateau was largely uninhabited. However, after the advent of the British at the turn of the century, hill tribes were resettled on the central plain. Soon after, the establishment of the tin mining industry attracted workers and traders from across the country. In the early nineteenth century, low human populations, absence of tsetse and mosquitoes and unlimited grassland made the Jos Plateau one of the most attractive environments for cattle in northern Nigeria. These favourable conditions drew Fulani pastoralists from the semi-arid regions who established themselves across the Plateau. From the 1970s onwards, the Fulani also settled on the lowland plains. Currently, the Jos Plateau is a highly populated cosmopolitan area, with inhabitants from across the country with a significant Muslim/Hausa presence (Fricke 1979; Awogbade 1983; Blench 2004). Rural areas are mostly inhabited by farmers of the original Plateau tribes with a significant minority of settled Fulani herders.

\section{Jos: conflict and civil strife}

The population of Jos city is composed of 'indigenes' from Plateau tribes (mostly Christians of the Birom, Anaguta and Afizere tribes), and Hausa-Fulani Muslim 'settlers' comprise a significant minority along with other settlers from across the country (Blench 2003). The conflict in Jos stems from competition between Muslims and Christians, 'settlers' and 'indigenes', respectively, for political power and representation in government. The Plateau tribes, who are mostly Christians, claim 'indigene' status and ownership of Jos city as the original inhabitants of the land. The Jasawa (Hausa Muslims of Jos) are currently classed as settlers which places them at a disadvantage in terms of social, political and economic benefits such as scholarships, places in state schools and employment in the civil service. The Hausa population in Jos wish to claim indigeneity in Jos, based on their longstanding settlement (fourth or fifth generation in some cases), and demand adequate representation in government and politics. This is vehemently opposed by the indigenes' who wish to keep these resources for themselves and feel that the settlers already have enough of an advantage over them in terms of numbers and affluence.

This tension has led to recurring violence in Jos North Local Government Area (LGA), since 1994. In August of 2001, a Hausa Muslim was appointed as the poverty eradication coordinator in the area. Tension escalated until September 2001 when it boiled over into riots that engulfed the whole city and was replayed in rural areas. In one week, over a thousand people were killed and tens of thousands of Muslims (including pastoralists) fled, never to return (Bawa and Nwogwu 2002). These were reported as religious riots, and those fomenting violence on either side were quick to incite their followers on religious grounds (Human Rights Watch 2001). There had been relative peace in rural areas of the high Plateau since the violence of 2001 and 2002. In November of 2008, the violence was repeated in disputes over the local government elections in Jos North. More than 780 people were killed in the ensuing riots (Higazi 2011). But unlike in 2001, the 2008 riot did not lead to violence in the countryside. There were also outbreaks of violence in November 2009 to January 2010. In December 2010 to January 2011, several churches were bombed during midnight mass on Christmas Eve and widespread riots followed. This time, the violence did spread into the rural areas on the Plateau (Higazi 2011; Krause 2011). Most of this violence was directed against Muslims - Hausa and Kanuri residents in historic tin mining settlements and adjacent Fulani agropastoralist communities - and most were driven out at this time. After a few months, the Fulani regrouped in certain areas and there were repeated attacks on Birom villages. Those affected on both sides lost their homes, farms, livestock and other assets. This current phase of rural violence began in January 2010 and has continued intermittently since then in three of the 17 local government areas in Plateau State: Barkin Ladi, Riyom and Jos South. The loss of life during this period has been even greater than that in 2001 to 2002, and the conflict has become protracted in these areas despite military interventions (Higazi 2013).

Off the Jos Plateau, the other major centres of conflict in Plateau State are Langtang and Wase local government areas on the lowland plains some $200 \mathrm{~km}$ southeast of Jos. The Tarok people are the indigenous tribe in this area, but there are substantial settlements of Hausa farmers and Fulani pastoralists (Blench 2004). The Tarok have maintained good relations with these settlers for a long time and are now themselves substantial cattle 
owners, often as a result of sending their sons to be trained in herding by the Fulani. The Tarok, moreover, have a long tradition of military service, and many of their leaders are ex-generals. Apparently, a fight broke out in Yelwa at the end of June 2002 between Christian and Muslim residents resulting in the burning of churches. It quickly spread to other communities in the area and degenerated into protracted guerrilla warfare with each side conducting armed reprisal raids on the other until the end of 2004 (Blench 2004). Cattle rustling by the Tarok was rife during this period, and of the 1.2 million cattle recorded in Wase LGA, an estimated 500,000 were lost to rustlers (Higazi 2008). In May 2009, state security forces stormed five villages in Wase LGA and hundreds of Fulani were forcibly loaded into trucks and driven 'back' to Bauchi, Gombe, Katsina and Jigawa states. Insecurity has discouraged both farming and herding in many areas with serious effects on livelihoods and food supply (Blench 2004).

\section{Methods}

To determine trypanosomiasis prevalence at 95\% confidence, a longitudinal two-stage stratified cluster sampling design was used where randomly selected cattle were the ultimate sampling unit and villages were clusters. Thirty individual villages were chosen using a $15 \mathrm{~km} \times 20 \mathrm{~km}$ grid applied over the study area as shown in Figure 2. A structured questionnaire, incorporating various participatory rural appraisal (PRA) techniques, was administered to livestock owners who participated in the trypanosomiasis survey. This allowed us to gather data for quantitative analysis of animal productivity and profitability to pastoralists; determine which social, economic, ecological and cultural factors influence animal health and disease control by herders and investigate knowledge, attitude and practices of animal husbandry and disease control.

Structured questionnaires are a standard method for collecting survey data. However, large-scale surveys and long questionnaires can be biased, unreliable and difficult to administer and analyse. PRA uses a range of qualitative sample survey methods to gather information by allowing local people to share and analyse their knowledge and experiences and to make plans based on this information (Chambers 1994). It is quicker and more cost-effective than long-term studies and uses a wide range of multidisciplinary information. It enables on-the-spot assessment and direct response to actual village-level problems. It also facilitates collection of standardised field data for use in more sophisticated databases. These qualitative methods may be used on their own or alongside more formal quantitative methodologies. Structured questionnaires incorporating several PRA techniques were administered to livestock owners in individual interviews and focus group discussions focusing on animal husbandry, pastoral livelihoods and the factors affecting them. Household/herd information was collected from 66 individuals for land ownership, mortality, herd dynamics and productivity to allow quantitative analysis of the data.

Households were assigned to wealth groups according to the categories devised by Famine Early Warning Systems Network for pastoral households (FEWS 2004) as shown in Table 1.

\section{Results}

\section{Source of income}

Livestock sale was the most important source of cash income amongst households, accounting for $52 \%$ of pastoral income across the study area as shown in Figure 3, ahead of crops (22\%) and milk (12\%). In terms of individual household income diversity, $30 \%$ of households relied on livestock as their sole source of income as shown in Figure 4. Forty percent supplemented the income from livestock with crops and 15\% with milk. Fifteen percent gained additional income from off-farm activities, mostly mining and sale of firewood.

\section{Land holdings}

Land ownership was universal, with all households owning a piece of land. The majority of households (61\%) owned 1 to 10 acres (Figure 5). The average amount of land owned was 17.9 acres, of which 10.9 were used for cropping while 7 were used for livestock. This illustrates the general trend of land use primarily for cropping purposes. Livestock were generally grazed on commons/fallow/unused land and only tethered at night on land owned by the household.

\section{Crop farming}

All households were engaged in crop farming. One hundred percent of households grew maize, 91.7\% grew vegetables (potatoes, lettuce, carrots, peas, cabbages, etc.) and $76.4 \%$ grew millet (Figure 6). All recipients grew more than one crop and the average number of crops grown was four. All but three of the 30 households used manure from their own cows (91.9\%) and commercial fertilisers to enhance crop yield and quality, but less than half $(40.5 \%)$ used herbicides.

\section{Cattle holdings}

Herd size was very variable, ranging from 7 cattle to 5,015 cattle. The herd size distribution was bimodal, with peaks in the range 10 to 20 cattle and 50 to 100 cattle (Figure 7). The average herd size was 253 cattle. However, when the four outlier herds with $>1,000$ animals were removed from the sample, the average herd size fell to 78 cattle. All households owned livestock other than cattle, with most of them keeping small 


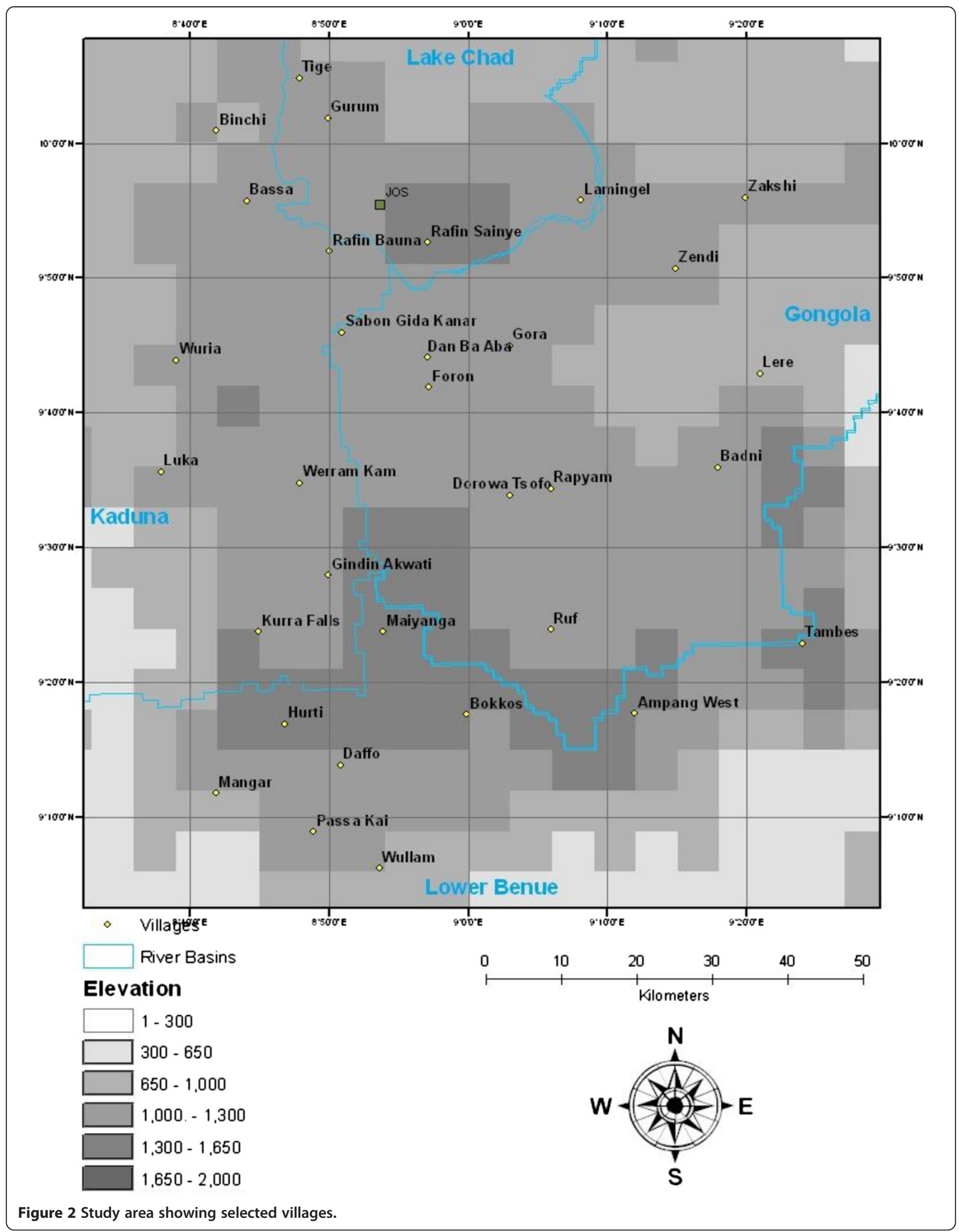


Table 1 Pastoral household wealth grouping criteria (FEWS NET 2004/5)

\begin{tabular}{lcll}
\hline Wealth group & Household size & Livestock & Area planted \\
\hline Poor & 3 to 5 & 5 to 10 cows, 10 to 26 shoats & 1 to 2 ha with household labour \\
Middle & 7 to 8 & 15 to 50 cows, 35 to 100 shoats & 3 ha with household labour \\
Better off & 8 to 13 & $50+$ cattle, 100+ shoats & 5 ha with household labour and hired hands \\
\hline
\end{tabular}

ruminants and chickens for household consumption and/or sale and dogs for hunting and/or security.

\section{Herd composition}

The age and sex of the sampled animals were recorded. Since the sampled animals were a good representative sample of the total herd, this gives an indication of the total herd composition. The sampled animals consisted of $74.1 \%$ (confidence interval: $73.1 \%$ - 75.1\%) females and $25.9 \%(24.9 \%$ - 26.9\%) males.

When considered by age group, $8.3 \%(7.5 \%-8.7 \%)$ of the herd were young calves below 6 months old, of which $3.8 \%(3.4 \%-4.2 \%)$ were males and $4.5 \%(4.0 \%-$ $4.8 \%)$ females. The overlapping confidence intervals indicate that there is no significant difference in sex ratio. Juveniles aged between 6 months and 2 years of age accounted for $25.3 \%(24.2 \%-26.2 \%)$ : $12.5 \%(11.7 \%-$ $13.3 \%)$ males and $12.8 \%(12.0 \%-13.6 \%)$ females. The overlapping confidence intervals indicate that there is no significant difference in sex ratio. Those above 2 years old were $66.4 \%(65.4 \%$ - 67.6\%): $9.6 \%$ (8.9\% - 10.3\%) males and $56.8 \%(55.6 \%$ - 57.9\%) females (Figure 8). There is no overlap in confidence intervals, indicating that there is a significant difference in sex ratio in this age group. There is no overlap in confidence interval between the three age groups, indicating a significant difference in age group composition.

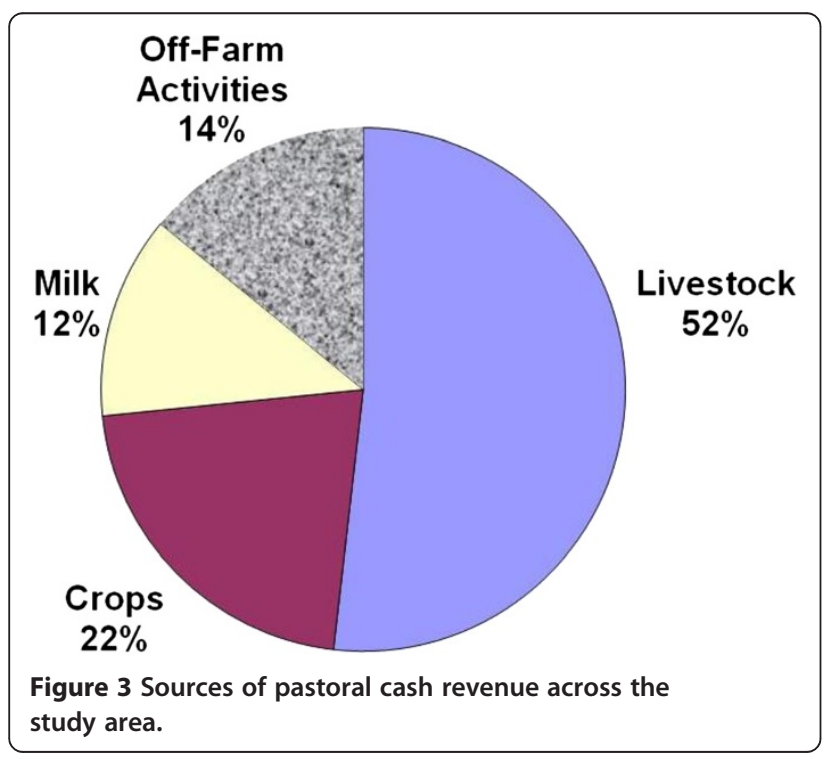

\section{Herd productivity}

Information on herd size, births, deaths, sales, purchases and prices was collected from individual members of focus group discussions using PRA techniques embedded in a structured questionnaire. Mean values per herd/ household are presented in Table 2. The average pastoral cattle herd contained 253 cattle, consisting of 21 calves below 6 months, 64 juveniles between 6 months and 2 years, 143 cows and 25 bulls. In the course of one year, 15 calves would be born (adding 5.8\% - the herd) and 2 of these would die $(12.7 \%$ calf mortality rate). Sales would consist of eight adult cattle (3.2\% of herd) sold for an average price of USD 681 each, and three yearlings (1.0\% of herd) would be purchased for an average price of USD 309 each. Nine cattle would die (3.5\% of herd) and one ( $0.4 \%$ of herd) would be slaughtered for ceremonial purposes. Natural herd growth (births to deaths) would be four cattle (1.6\% of herd). Actual herd growth is obtained by adjusting for net offtake (sales + slaughters) that is for eight cattle (3.6\% of herd) offtaken less three $(1.0 \%$ of the herd) purchased, so six (2.6\% of the herd). In this description, cattle numbers were rounded to whole numbers, but percentages reflect the fractions. The actual herd growth, recorded for the whole cattle population, was negative, at $-1.2 \%$ (Table 2 ).

These herd productivity results were compared to those collected in 1975 by Pullan and Grindle (1980) to assess changes over time as shown in Table 2. Prices from 1975 were adjusted for inflation to generate 2008 equivalents

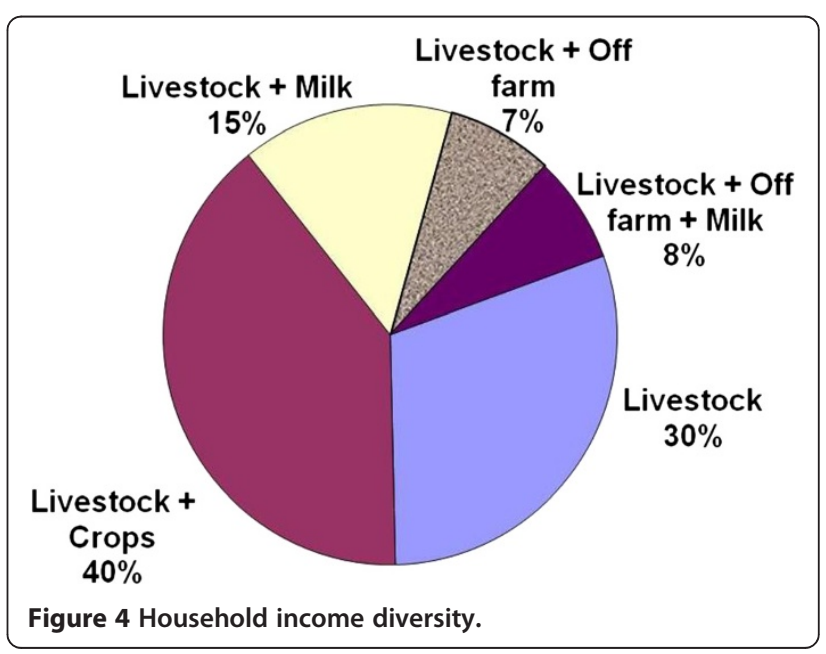




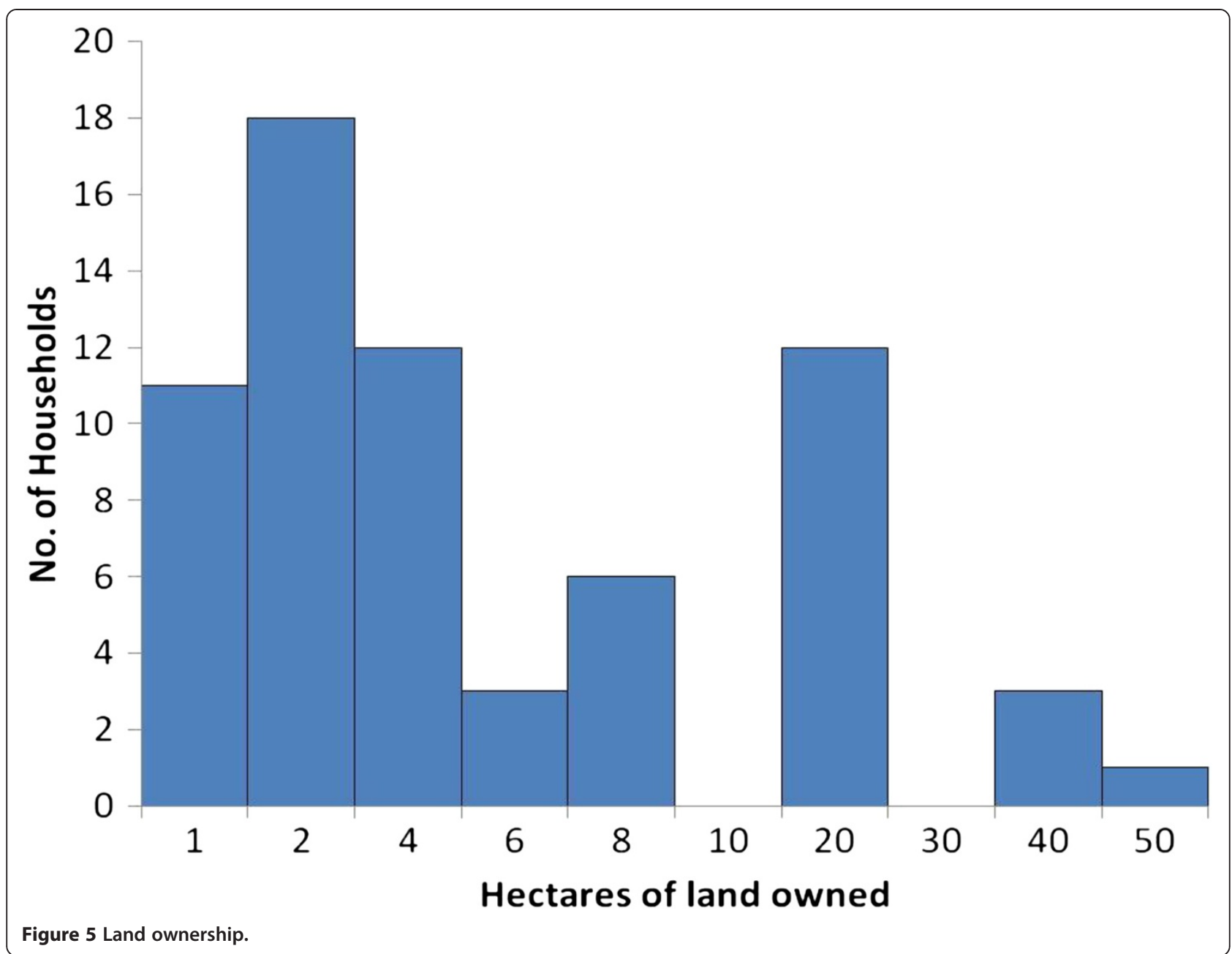

(Central Bank of Nigeria 2007). There were no statistically significant differences between the two data sets.

\section{Wealth grouping}

Analysis of households by livestock holdings revealed that $43.9 \%$ of households were 'better off', $50 \%$ were in the 'middle' group and only 6.1\% were 'poor' (Figure 9). Analysis by land holdings showed that $37.9 \%$ of households were 'better off', $7.6 \%$ were in the 'middle' group and $54.5 \%$ were 'poor' (Figure 10).

\section{Conflict, competition and migration}

Results showed that of the 66 respondents, 44 (67\%) practised transhumance: $4(6 \%)$ only during the dry season, $10(15 \%)$ only during the wet season and 30 (46\%) during both wet and dry seasons. Twenty-two households did not practise transhumance. The reasons given by respondents for their migration practices in the dry and wet seasons are shown in Figure 11. Figure 12 illustrates the seasonal calendar and migration periods.
Dry season migration is practised by herders in search of adequate pasture and water: Climatic conditions mean that there is very little grass or water available during the dry season. Pastoral access to these scant resources is further restricted by dry season farming activities practised by the indigenous populations that are common on the Jos Plateau and take priority over cattle grazing. This means that even when grazing and/ or water is available, cattle may not be able to access it and herders move them to areas with less land pressure.

Rainy season migration is practised for:

a) Accessible grazing and water: Pasture and water are widely available in the wet season, but uptake of more commercial and intensive farming methods and a higher proportion of cash crops mean that arable farmers increasingly demand more land and water for irrigation, so herders are marginalised.

b) Avoidance of farmers' crops: Increasing populations and land pressure have intensified farmer/pastoralist 

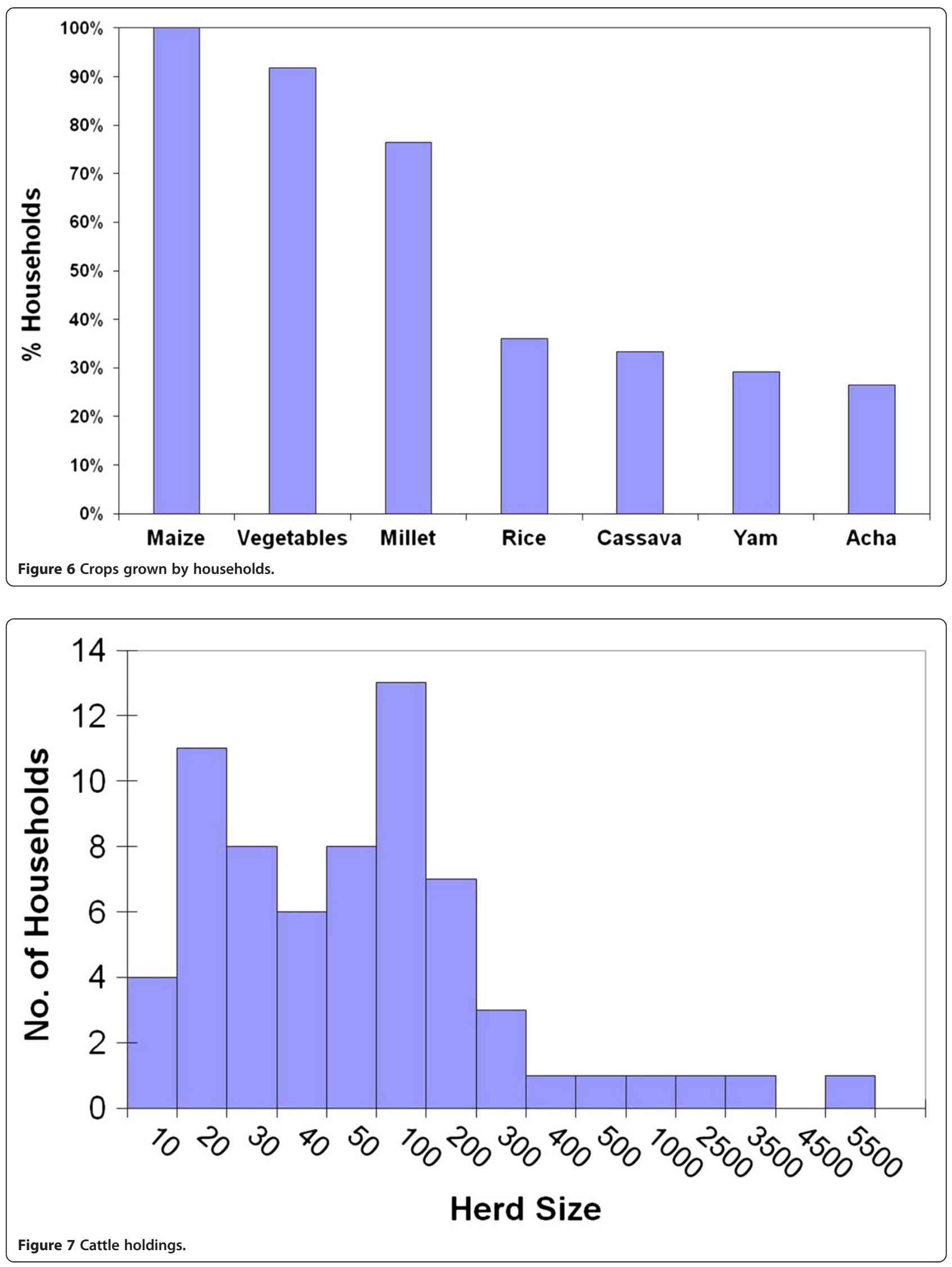


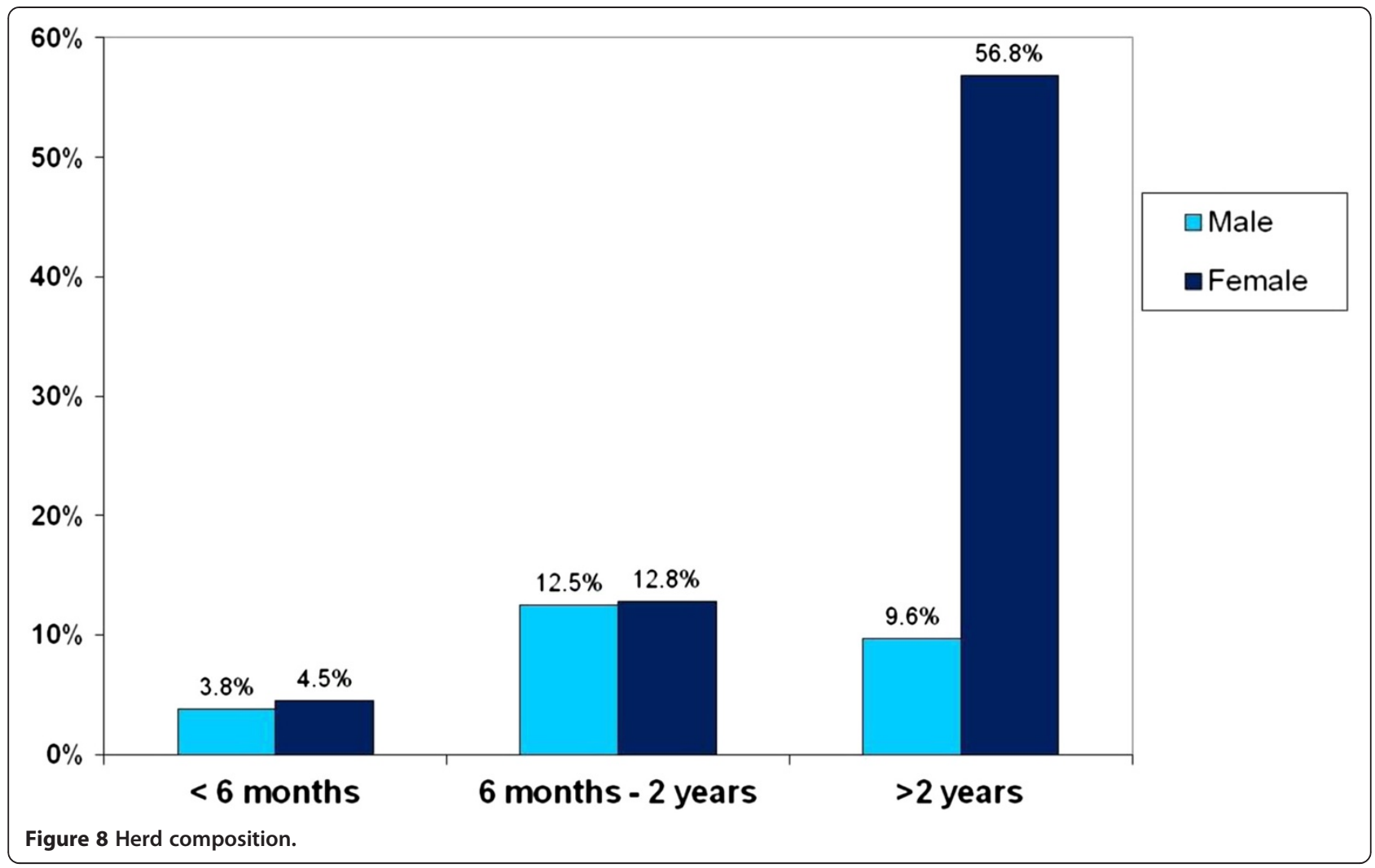

conflicts and increased the frequency of animals trampling crops. In many areas, these issues have been resolved simply by asking pastoralists to remove their cows from the village from the time the crops appear above ground until harvest.

c) Avoidance of tsetse and/or biting flies: In areas where flies are a severe nuisance, cattle are moved to more favourable areas of the Plateau or to nearby lowlands.

Table 2 Mean productivity parameters per household herd (with confidence intervals)

\begin{tabular}{lll}
\hline & $\mathbf{1 9 7 5}$ & $\mathbf{2 0 0 8}$ \\
\hline Starting stock & $126(19-232)$ cattle & $253(62-443)$ cattle \\
Closing stock & $141(16-267)$ cattle & $249(60-440)$ cattle \\
\% Change in herd & $+7.8 \%(-17.0 \%-+25.6 \%)$ & $-1.2 \%(-2.8 \%-+0.3 \%)$ \\
Births & $28.5 \%(4.0 \%-53.0 \%)$ & $5.8 \%(4.0 \%-7.6 \%)$ \\
Deaths & $8.0 \%(0 \%-55.3 \%)$ & $3.5 \%(2.1 \%-4.9 \%)$ \\
Sales & $10.4 \%(5.3 \%-52.6 \%)$ & $3.2 \%(2.2 \%-4.3 \%)$ \\
Purchases & $1.2 \%(0 \%-2.3 \%)$ & $1.0 \%(0.4 \%-1.7 \%)$ \\
Price bought & $\$ 769.5(115.2-1.423 .9)$ & $\$ 308.9(265.0-352.8)$ \\
Price sold & $\$ 559.1(188.3-923.00)$ & $\$ 680.9(609.2-752.5)$ \\
Natural herd & $14.7 \%(8.2 \%-21.2 \%)$ & $1.6 \%(0.4 \%-2.8 \%)$ \\
growth & & \\
Actual offtake & $11.7 \%(2.2 \%-21.3 \%)$ & $3.6 \%(2.4 \%-4.7 \%)$ \\
\hline
\end{tabular}

\section{Discussion}

\section{Sources of household income}

Income diversity is significant, but 30\% of households are still reliant on a single source - livestock sales. Only $16 \%$ engaged in off-farm activities, mostly labourintensive mining/sale of firewood rather than investment/trade. This is an indicator that pastoral livelihoods in this area retain a certain degree of vulnerability as higher income diversity and diversification into trade both reduce vulnerability to risks or shocks.

On the Jos Plateau, the proportion of better off herders is higher than average figures for pastoralists (10\% poor, $10 \%$ better off and $80 \%$ in the middle group; FEWS 2004). This indicates that their relative 'wealth' and local opportunities (land acquisition, proximity to towns, good road networks, good market access, high demand and high price for vegetables) have encouraged voluntary diversification into growing cash crops in $39 \%$ of households for whom these crops bring in $25 \%$ of their cash income. The fact that the remaining $61 \%$ of households were unable to take advantage of these conditions to diversify into growing cash crops is supported by the results of the wealth grouping by land holdings that show that $54.5 \%$ of households were 'land poor'. Those in this category lack the opportunity of land acquisition and are therefore unable to diversify into cropping. 
The other main source of income for income-diverse households was the sale of milk. Milk is the main subsistence product of cattle. There is therefore constant competition for milk, between human consumption, calf consumption and sale which may be responsible for the low percentage of households (28\%) gaining income from the sale of milk. There is evidence elsewhere that only better off pastoral households consume milk while poorer households prefer to sell it and buy grain to eat (Niamir 1982). The low number of households gaining income from milk is also as expected based on the wealth grouping results - a higher number of better off households will reserve their milk for consumption by humans and calves while only the few poorer households will sell theirs.

Another important obstacle to diversification into the dairy trade is market exclusion, for which there are two reasons. Firstly, the main potential for pastoral dairying is an informal market serving high urban demand; however, pastoralists in remote areas simply do not have access to this market. Secondly, the entire trade in pastoral dairy products faces stiff competition from imported powdered milk and intensive, peri-urban dairy farms. This competition tends to reduce demand for pastoral dairy products that are viewed as unhygienic in comparison. The lack of demand is a very important constraint to market access as well as to any prospects for its improvement. Demand for pastoral dairy products has been identified as the limiting factor to market participation and as an important pre-requisite for interventions designed to increase market access for pastoralists, e.g. establishment of milk collection centres and improved road network (Michael 1987; Little 1989). Since income from the pastoral dairy trade is controlled by women, this also has serious implications for gender empowerment and household economics.

\section{Wealth grouping}

The results showed a discrepancy between wealth grouping by land and wealth grouping by livestock holdings. Grouping by livestock holdings showed that $43.9 \%$ of

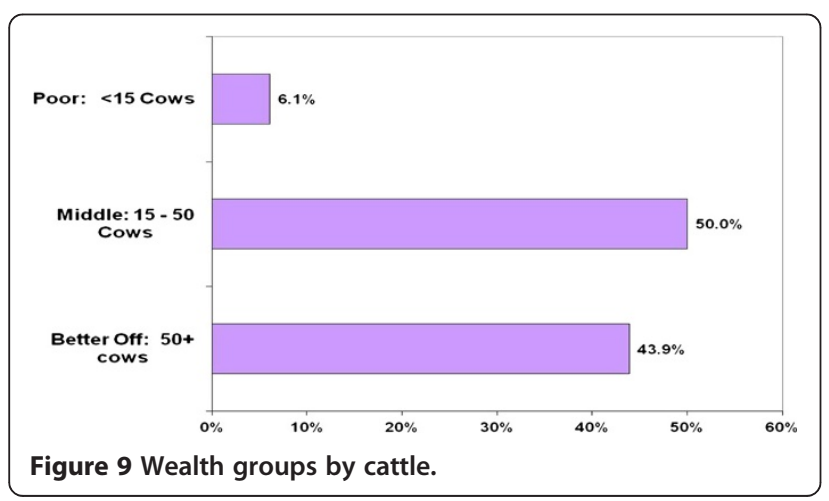

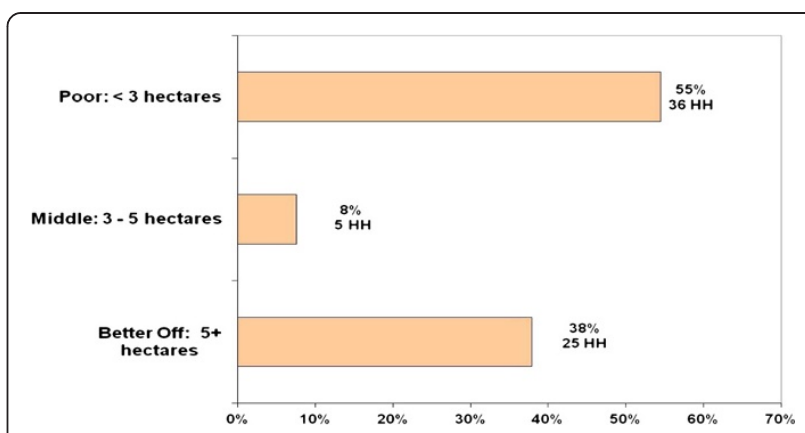

Figure 10 Wealth groups by land.

households were 'better off', 50\% were in the 'middle' group and only $6.1 \%$ were 'poor'. But grouping by land holdings showed that $37.9 \%$ of households were 'better off', $7.6 \%$ were in the 'middle' group and $54.5 \%$ were 'poor'. This shows that although few of the Fulani on the Jos Plateau are poor in terms of livestock, many are still land-poor. There is a continuous distribution amongst wealth groups by livestock holdings, but the distribution of wealth groups by land was bimodal: households owned either a lot of land or very little, with few households in the middle category. This pattern of land ownership may be due to the duration of settlement of different groups of Fulani. Fulani that have been settled for longer are more likely to be granted permission to acquire land, but they are also more likely to be attracted by the advantages of mixed farming than those who have only recently settled in an area. This distribution may also be linked to the amount of labour required to till large pieces of land once acquired. Larger, wealthier households are more likely to have spare hands for farm labour or spare cash to hire labourers. The majority of Fulani with large land holdings contract the tilling and weeding to labourers from the indigenous population, but family labour was used for harvesting. There were no reports of animal traction used by either the Fulani or indigenes for tilling their land.

The results of wealth grouping by livestock holdings show that few herders are in the poor $(6.1 \%)$ group while the majority are in the middle (50\%) and better off groups $(43.9 \%)$ on the Jos Plateau compared to average figures from FEWS NET wealth analysis which showed $10 \%$ pastoral households to be poor, $10 \%$ - be better off and $80 \%$ in the middle group (FEWS 2004). This is better than the national pastoral poverty incidence of $28 \%$ recorded by Rass (2006) for Nigeria (the lowest in West Africa, compared to $48 \%$ in neighbouring Chad and Niger, which had the highest poverty incidence amongst pastoralists in West Africa). Despite this comparatively well-to-do status, most of the study households' wealth is invested in their livestock. This means that their dayto-day living standards are lower than would be 


\section{Reasons for Migration}

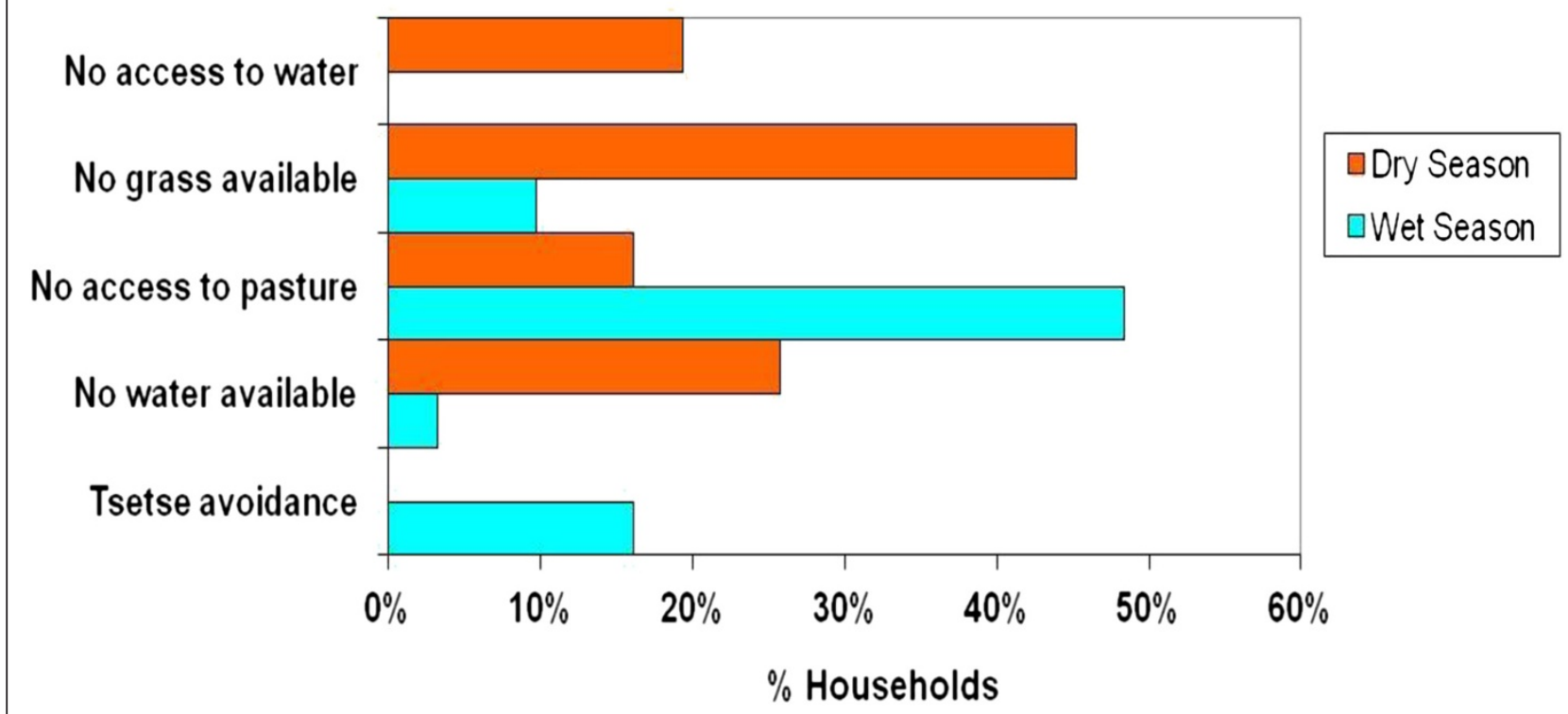

Figure 11 Reasons for seasonal migration.

expected and that their livelihoods are vulnerable to the risks of disease, droughts and conflict.

\section{Crops}

The pastoral Fulani group in the study area have become agro-pastoralists who own land and grow their own staples (maize, millet) as well as cash crops (vegetables). They are even willing to invest cash in agricultural inputs such as herbicides and fertiliser. The successful adaptation to agro-pastoralism has resulted in higher food security and income diversification for the Fulani on the Jos Plateau. Typically, pastoralists are highly dependent on cash purchase of food to satisfy their nutritional need, but the widespread adaptation to agropastoralism reduces this dependency and frees up cash for other uses. The adaptation to agro-pastoralism and reduced dependence on food purchase is also an indication of wealth status. Poorer pastoralists typically

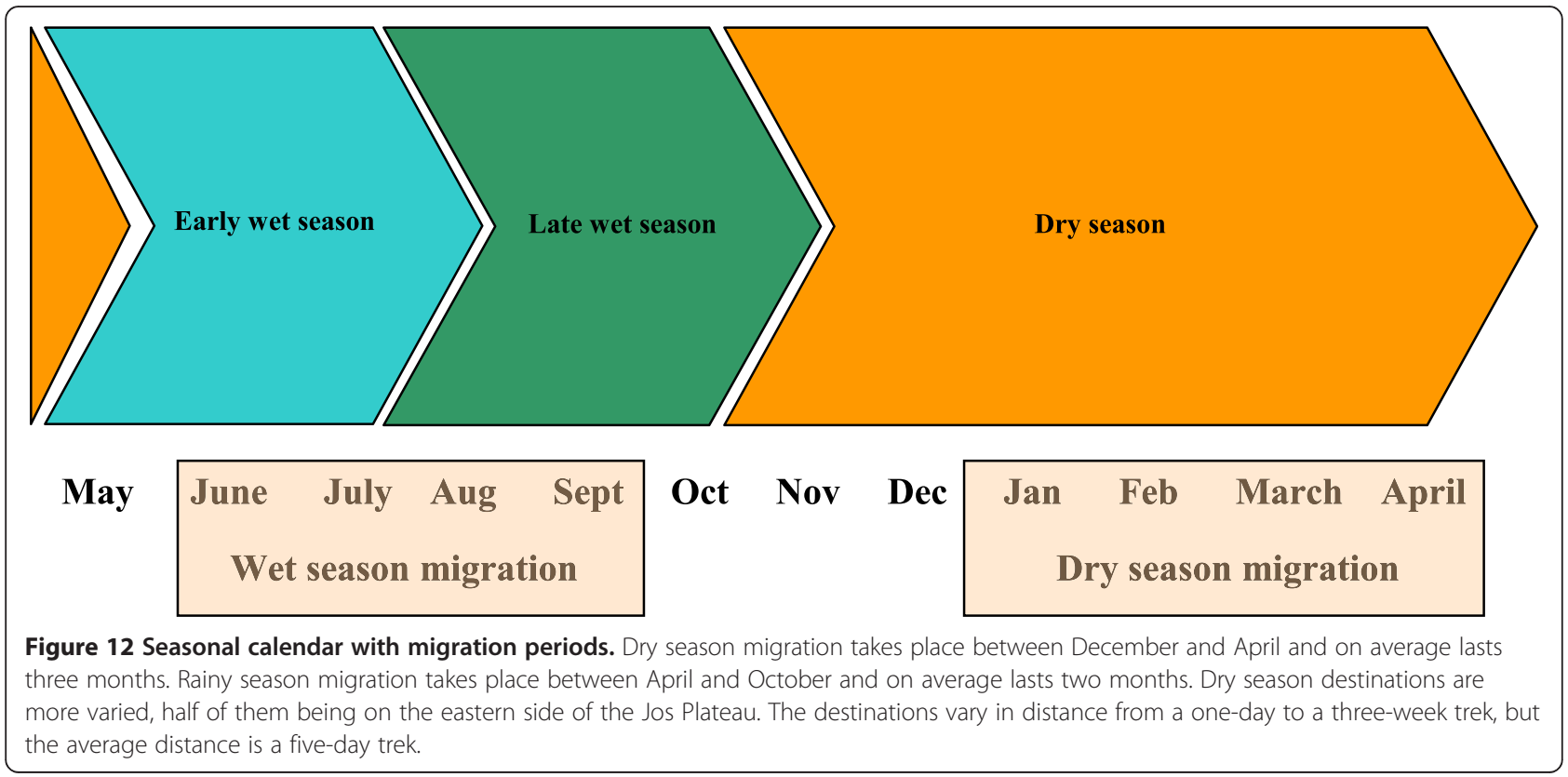


purchase $70 \%$ of their food requirements whereas those who are better off only purchase $15 \%$ of requirements with $80 \%$ being supplied by their own crops (FEWS 2004).

This transition may be due to the breakdown of viable exchange relations between pastoralists and local farmers, forcing the Fulani to acquire land and grow their own food, instead of getting it from farmers in exchange for dairy products and manure. It may also simply be a natural income diversification strategy enabled by the longterm settlement of the Fulani in this area. This is almost certainly the case in the $23 \%$ of households who own large amounts of land and sell most of their crops for cash. However, it is likely that the former reason is responsible for the widespread uptake of arable agriculture observed. It is interesting to note that the Fulani, along with local farmers, mostly grow crops that provide little or no residues (hay and threshed grain heads) for animals to graze.

\section{Herd composition}

Herds were composed of $76 \%$ females and $24 \%$ males. Further analysis revealed that there were slightly more female calves aged $<6$ months and equal numbers of juveniles aged 6 months to 2 years, but in adult cattle aged $>2$ years, the number of females was six times the number of males. This shows that equal numbers of male and female calves are born but that a large number of males exit the herd when they reach the age of two. The high percentage of adult females in the herd is characteristic of a dairy herd, where the husbandry system is geared towards maximising milk production and herd growth. The preponderance of adult females in the herd is a consistent feature of milk- and herd growth-oriented extensive cattle production systems throughout Africa (Pullan 1979; Wagenaar et al. 1986; Agyemang et al. 1997; Roderick et al. 1998) and contrasts with animal traction-oriented cattle production systems, where numbers are similar or males predominate (Ahmedin and Hugh-Jones 1995; Ocaido et al. 2005). However, in our study, the proportion of females in the herd, at $74 \%$, is high as compared to 70\% (Roderick et al. 1998), 70\% (Agyemang et al. 1997) and 67\% (Wagenaar et al. 1986) where some $4 \%-6 \%$ of the herd were oxen, probably used for draught and, in the same area, 71\% (Pullan 1979). This does indicate that in the study area, herders keep very few surplus males, fewer than in 1979 and fewer than elsewhere in the region. Mature males are preferentially sold when cash is needed.

\section{Herd productivity}

Reproductive efficiency was low but not untypical for the region. Cows in the region usually have their first calf at age 4 years and over - with Pullan (1979) finding a value of 60 months, Agyemang et al. (1997) 50 to
53 months and Wagenaar et al. (1986) 50 months. Thus, it is estimated that between $38 \%$ and $45 \%$ of the observed population in our study consisted of breeding females. This proportion is very similar to that for other African pastoral systems (Wagenaar et al. 1986; Agyemang et al. 1997; Roderick et al. 1998). The annual calving rate implied by the herd composition would thus be between $33 \%$ and $42 \%$. This is substantially lower than the $46 \%$ estimated by Pullan (1979). The optimum calving rate expected in intensive commercial farming systems is $100 \%$, i.e. one calf per cow per year. However, results from studies on Fulani herds under similar traditional management lead us to expect that $50 \%$ calving rate in these circumstances reflects a number of factors. In these production systems, low calving rates are usually attributed to the practice of allowing calves to suckle their dams for very long periods of up to two years. This is done for two main reasons: first, to provide robust nutrition for calves, given the uneven availability of pasture, and second, to ensure a constant supply of milk for sale and household needs. It has also been argued that calving every other year is sustainable for the cows in extensive systems, with limited grazing and some transhumance (Hill 1995). Lactation length is a significant factor in the determination of calving interval because the stress of lactation delays the onset of oestrus until the calf is weaned. However, here the impact is particularly marked. The effects of disease and poor nutrition exacerbate the situation, so that this means that on average, each cow produces a calf once every 28 to 36 months. The average calving interval for White Fulani cows in Nigeria is 13 to 14 months under intensive management (Wheat and Broadhurst 1968; Wheat et al. 1972; Oyedipe et al. 1982) and 24 to 27 months under traditional management (Pullan 1979; Otchere 1983), as against 20 months in Mali's Niger Delta (Wagenaar et al. 1986) and 22 months in central Mali (Wilson 1986) as well as The Gambia (Agyemang et al. 1997) where it was observed that a subset of cows calved regularly and others very infrequently. Calf mortality in the first six months of life is low at $12.7 \%$ compared to expected values of $20 \%-40 \%$ for the first year (Pullan and Grindle 1980; Wagenaar et al. 1986), but this is not enough to compensate for the poor reproductive performance.

Mortality was low at 3.5\%, much lower than the $16.3 \%$ recorded by Wagenaar et al. (1986) and 8.1\% recorded by Pullan and Grindle (1980). This may be because of generally lower levels of disease than in the past as well as increased access of herders to curative drugs.

Sales were equivalent to $3.2 \%$ of the herd, again lower than the $5.6 \%$ recorded by Wagenaar et al. (1986) and $10.4 \%$ by Pullan and Grindle (1980). This may be because the Fulani on the Jos Plateau are now all agropastoralists and are less dependent on cash from sale of 
cattle to buy food. However, herds are much larger now, and more money is realised per sale, even after allowing for inflation, so selling a smaller percentage of the overall herd is sufficient. Purchases of new stock were equivalent to $1.0 \%$ of the herd, comparable to the $1.2 \%$ recorded by Pullan and Grindle (1980).

Natural herd growth (often described as potential offtake) was $1.6 \%$ and actual offtake $3.6 \%$. Both figures are very low, much lower than the $14.7 \%$ natural herd growth and $11.7 \%$ actual offtake previously recorded by Pullan (1980). This points to reduced productivity over time. The reduction in productivity is probably linked to increased land pressure and environmental degradation and its knock-on effects on cattle nutrition and management. It may also be linked to the presence of trypanosomiasis which was absent from the Plateau at the time of the study by Pullan (Majekodunmi et al. 2013a) which is primarily a disease of production. Actual offtake was more than potential offtake, indicating that herders are unable to meet their need for cash from livestock sales without reducing the size of their herd. This factor is probably responsible for closing stock levels (average herd size of 249) being lower than starting stock (253) and the $-1.2 \%$ average change in herd size.

Figures obtained previously from Pullan and Grindle (1980) were compared to those collected in this survey. There were no statistically significant differences between the two data sets. However, there are some apparent changes that can be deduced from the figures:

- Mean herd size has increased and is more variable. This could be due to increased polarisation into better off versus poor households or to a simple increase in the number of better off households. Wealth grouping results support the latter because although there is a higher proportion of better off households, there is also a high proportion of households in the middle category.

- Variability in annual change in herd size has decreased, showing that herd sizes are more stable.

- The number of births is less variable, but seems to be decreasing, pointing to a reduction in cattle productivity.

- Variability in both natural herd growth (potential offtake) and actual offtake has decreased, pointing to increased stability. However, actual offtake in this study is more than potential offtake, which also indicates reduced productivity and ultimately a willingness to reduce herd size and compromise long-term herd growth, if viable breeding females are sold.

- Sale and purchase prices are both less variable. The price of stock bought is much lower than it was, but on average, herders earn USD 120 more per animal sold.
When taken together, these factors indicate that the overall livestock enterprise is more stable but the overall productivity has also decreased.

\section{Effects of conflict, competition and migration}

Results show that $67 \%$ of all households practised transhumance and that over half of these practised both wet and dry season migration. Poor availability of resources is the main driver for dry season migration, being the reason cited by $71 \%$ of respondents, almost twice the number who cited poor access as the reason for migration. However, poor access to available resources is the major driver for wet season migration, being the reason cited by $48 \%$ of respondents, almost four times the number $(13 \%)$ who cited lack of resources as the reason for migration.

It is easy to see how the poor pasture and dwindling water supplies caused by the long harsh dry season force herders to move their cattle to areas where the dry season is shorter and its effects less severe. This is an ageold feature of pastoral life. Wet season migration is an unfortunate consequence of natural resource competition and marginalisation of pastoralists by farming communities. The issues surrounding lack of access to abundant pasture and water during the wet season are more involved and require a study of the relationships between Fulani pastoralists and the indigenous farming peoples.

The most significant feature of rural dynamics in Nigeria in the twentieth century has been demographic expansion and the consequent expansion of cultivation (Blench 2003). Agricultural expansion on the Jos Plateau has also been fuelled by technological advances: improved seed varieties, irrigation pumps and the introduction of new crops like maize and potatoes and vegetable gardening (Blench 2003). Farmers on the Plateau previously practised rainfed agriculture based on cereals that grew well on eroded soils and produced high-quality residues for animals. This facilitated a stable system of exchange between farmers and pastoralists: grain for dairy products and crop residues for manure. At this time, mine ponds and river valleys were of little use to farmers but were valuable to pastoralists who were given free access but not ownership rights. Dry season farming of new crops - maize, sugarcane and Irish potatoes - was introduced in the 1960s and greatly encouraged by World Bank-funded agricultural development programmes in the 1970s. Year-round large-scale vegetable gardening also began in the 1980s, assisted by the appearance of small petrol irrigation pumps. These are all fertiliser-based crops that produce no useful crop residues for cattle feed, so the farmer-pastoralist exchange system has broken down. Advances in livestock management and disease control over time have also led to agricultural expansion on the part of pastoralists. This has led to overstocking and 
overexploitation of pasture. Very large numbers of cattle have caused degradation on a massive scale, and sheet and gully erosion have long been widespread on the Jos Plateau (Pullan 1980; Blench 2004).

Given the increasing land pressure and agricultural expansion by both parties, previous land use schemes became unsustainable and have broken down. All riverine plots which previously provided lush pasture and watering points have become extremely valuable to farmers. Therefore, pastoralists' access rights have been revoked and they have been effectively excluded from the enjoyment of natural resources that were previously held in common. Pastoralists have adapted to this increasing marginalisation by sending their cows off the Plateau for longer periods each year. There are several important consequences of the increase in transhumance in response to these issues. Management becomes more difficult as herds are split and increased labour is required to herd migrating cattle (which are also more vulnerable to security risks). Cattle suffer poorer health and productivity due to malnutrition, stress and fatigue of trekking, increased morbidity of underlying diseases and increased contact with disease and disease vectors during transhumance. There are also many long-term, indirect effects of this climate of recurring violence, marginalisation of pastoralists and constant risk of conflict. These factors often reverse ongoing development processes in pastoral livelihoods - herders are less likely to invest in new assets/ technologies or to practise income diversifications in such an atmosphere of uncertainty (Mahama et al. 2005; Majekodunmi et al. 2013b). The outbreaks of urban violence in Jos and its environs exacerbate the growing natural resource conflict in the rural areas.

Environmental security scholars believe that these rural conflicts are manifestations of herder-farmer conflict based on competition for land and natural resources, fuelled by climate change such as desertification in the Sahel (Homer-Dixon 1999; Herskovits 2010). Political ecologists on the other hand argue that social, cultural and political considerations are more important than ecological factors in causing these violent conflicts (Hartmann 2001; Moritz 2010).

Our experience has been that natural resource conflicts unrelated to the ethno-religious conflicts previously described tend to be settled amicably on the Jos Plateau as reported by respondents. Traditional conflict mitigation/resolution mechanisms are active there and have successfully managed to develop schemes for the

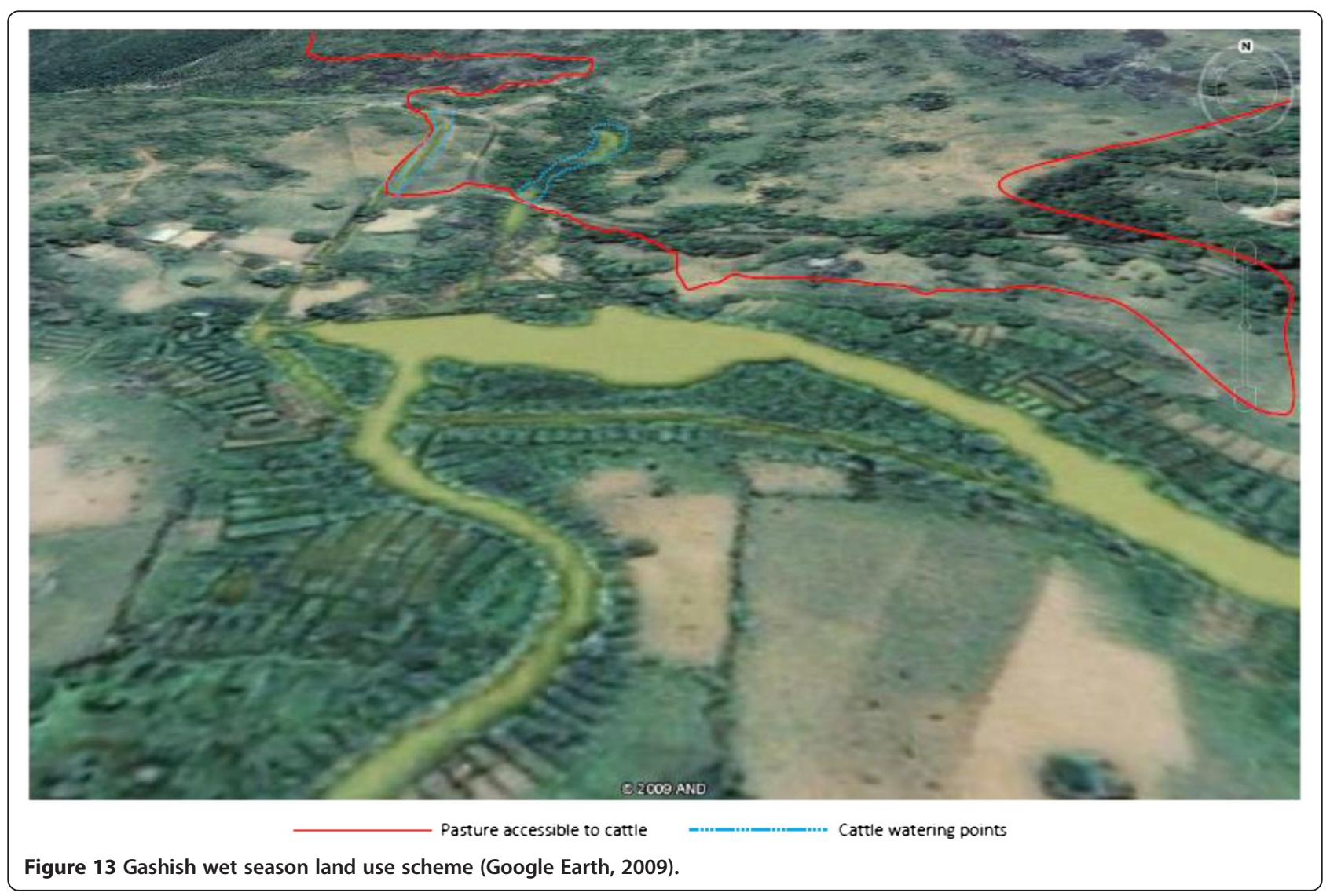


shared use of key resources. The pastoralists interviewed described practising increased migration during both wet and dry seasons to comply with these agreements. This is reinforced by Blench (2004) who points out that natural resource conflicts on the Jos Plateau are 'usually settled informally and the types of violent clashes characteristic of some other northern states were not characteristic of the Plateau'. He presents resource use maps as evidence of agreements on natural resource use between farmers and herders which were still in use at the time of this study (Figure 13). Higazi (2013) is of the opinion that the complexity of the rural violence has tended to be lost on analysts and reporters, who in seeking to explain what is happening from afar have over-simplified the conflicts as "farmer-herder clashes" there are other important aspects to the violence'. These include revenge for past attacks, economies of conflict (cattle rustling and armed robbery for gain), resource scarcity, decreasing interdependence of pastoral and agricultural economies, cultural/religious differences between herders and farmers and institutional failures to resolve conflicts as well as the broader political and historical context (Blench 1984; Huraoult 1998; Moritz 2006; Tonah 2000; Blench 2004; Higazi 2011).

\section{Conclusion}

This survey of pastoral livelihoods of Fulani herders is set against a backdrop of agricultural change and general insecurity. The survey showed that the majority of pastoral households in the study area are better off or in the middle wealth categories and only a few are poor in terms of livestock holdings. However, many households are poor in terms of land holdings. Income diversity is significant but as many as 30\% of households still rely on one source of cash revenue: livestock sales. Pastoralists are less vulnerable to livestock disease but increasingly vulnerable to the risks of conflict and poor access to natural resources. Cattle productivity parameters are more stable, but the overall productivity has decreased and reproductive rates were particularly low. The amount of wealth concentrated in livestock, number of land-poor households and those still reliant on one source of income suggest that there is still a degree of vulnerability to the risks of disease, drought/dry season and conflict in pastoral livelihoods in the area.

This information gives us an improved understanding of factors affecting pastoral livelihood strategies and lifestyle choices, which is useful for targeting improvements and interventions and providing a solution to the current volatile situation. The target is clearly not poverty or livestock disease, although there is room for improvement on both. The target should be to increase productivity and sustainability and reduce vulnerability. The primary approach to achieving this is to settle the issues surrounding security, natural resource use and sustainable nutrition for cattle. The current extensive production system has clearly become unsustainable, and the extent to which Fulani pastoralists can adapt their livelihood strategies to integrate with prevailing conditions will determine the viability of their livelihoods in the future.

\section{Competing interests}

The authors declare that they have no competing interests.

\section{Authors' contributions}

AOM conceived of the study and participated in its design, coordinated the fieldwork, analysed the data and drafted the manuscript. AF and CD carried out the data collection and translations in the field. APMS and SCW participated in the study design and coordination, data analysis and manuscript revision. All authors read and approved the final manuscript.

\section{Authors' information}

$\mathrm{AOM}$ is an epidemiologist at the University of Edinburgh, working on the control of parasitic and zoonotic diseases. AF is a veterinarian at the Nigerian Institute for Trypanosomiasis Research. CD is principal livestock technologist with the Nigerian Institute for Trypanosomiasis Research. APMS is a livestock and health systems economist. SCW is the Director of the Global Health Academy and Assistant Principal for Global Health at the University of Edinburgh.

\section{Acknowledgements}

We would like to thank Augustine Igweh, Everestus Yanan, Musa Sule and the Nigerian Institute for Trypanosomiasis in Vom, Nigeria, and The Plateau State Ministry of Agriculture for their assistance facilitating this project. We would also like to thank Dr K. Picozzi and Dr M. Thrusfield for their contributions to the wider project. Our sincere appreciation goes to the community leaders of the study villages on the Jos Plateau.

\section{Funding}

This study was supported by the UK's Biotechnology and Biological Sciences Research Council (BBSRC) under the 'Combating Infectious Diseases in Livestock for International Development' (CIDLID) scheme (AOM, SCW, APMS); the European Union's Seventh Framework Programme (FP7/2007-2013) under grant agreement no. 221948, Integrated Control of Neglected Zoonoses (ICONZ) (SCW, CD, APMS); the DfID Research Into Use Programme (SCW, APMS) and a European Science Foundation Senior Investigator(s) award Investigating Networks of Zoonosis Innovation (INZI) (SCW).

\section{Author details}

${ }^{1}$ Division of Pathway Medicine and Centre for Infectious Diseases, School of Biomedical Sciences, College of Medicine and Veterinary Medicine, The University of Edinburgh, Chancellor's Building, 49 Little France Crescent, Edinburgh EH16 4SB, UK. ${ }^{2}$ Nigerian Institute for Trypanosomiasis Research, P.M.B. 1303, Vom, Plateau State, Nigeria.

Received: 16 September 2014 Accepted: 22 October 2014

Published online: 29 November 2014

\section{References}

Agyemang, K, RH Dwinger, DA Little, and GJ Rowlands. 1997. Village N'Dama cattle production in West Africa: Six years of research in The Gambia. Nairobi/Banjul: International Livestock Research Institute/Kenya and International Trypanotolerance Centre.

Ahmedin, J, and ME Hugh-Jones. 1995. Association of tsetse control with health and productivity of cattle in the Didessa Valley, western Ethiopia. Preventive Veterinary Medicine 22: 29-40.

Awogbade, MO. 1983. Fulani pastoralism: Jos case study. Zaria: ABU Press.

Bawa, I, and V Nwogwu. 2002. The Jos crisis. In Hope betrayed? A report on impunity and state-sponsored violence in Nigeria, ed. E Sottas, I Chukwuma, and C Odinkalu. Geneva/Lagos: World Organisation Against Torture/Centre for Law Enforcement Education (CLEEN).

Blench, R. 1984. Conflict and cooperation: Fulani relations with the Samba and Mambila peoples. Cambridge Anthropology 9(2): 42-57. 
Blench, R. 2003. The transformation of conflict between pastoralists and cultivators in Nigeria. www.rogerblench.info. Accessed 20 June 2009.

Blench, R. 2004. Natural resource conflicts in North-Central Nigeria: A handbook and case studies. Cambridge: Mallam Dendo Ltd.

Catley, A. 2000. Notes on pastoral livelihoods in Africa. London: RWA International/Network UK.

Central Bank of Nigeria. 2007. Economic and financial review. Abuja: Federal Government of Nigeria.

Chambers, R. 1994. The origins and practice of participatory rural appraisal. World Development 22(7): 953-969.

Eldis.org. 2010. Livelihoods connect. www.eldis.org/go/livelihoods. Accessed 1 May 2011.

FEWS NET. 2004/5. Famine early warning system: National livelihood profiles. http://www.fews.net/sectors/medios-de-vida. Accessed 19 June 2009

Fricke, W. 1979. Cattle husbandry in Nigeria: A study of its ecological conditions and social-geographical differentiation. Heidelberger Geographischen Arbeiten, Heft 52. Heidelberg: Geographisches Institut der Universität.

Gunn, HD. 1953. Peoples of the plateau area of Northern Nigeria. Ethnographic survey of Africa, Western Africa, 7. London: International African Institute.

Hartmann, B. 2001. Will the circle be unbroken? A critique of the Project on Environment, Population, and Security. In Violent environments, ed. Nancy L Peluso and Michael Watts, 39-62. Ithaca: Cornell University Press.

Herskovits, J. 2010. Nigeria: Critical time for Nigeria's future. Guest Column, 14 March 2010. http://allafrica.com/stories/201003150001.html. Accessed 15 Sept 2014.

Higazi, A. 2008. Social mobilization and collective violence: Vigilantes and militias in the lowlands of Plateau State, Central Nigeria. Africa: Journal of the International African Institute 78(1): 107-135.

Higazi, A. 2011. The Jos crisis: A recurrent Nigerian tragedy. Discussion Paper No. 2. Abuja: Friedrich Ebert Stiftung.

Higazi, A. 2013. Rural insecurity on the Jos Plateau, Nigeria: Livelihoods, land, and religious reform among the Berom, Fulani, and Hausa. Oxford: Nigeria Research Network.

Hill, DH. 1995. The cattle and buffalo of Africa: Management. Outlook on Agriculture 24(3): 155-161.

Homer-Dixon, TF. 1999. Environment, scarcity, and violence. Princeton: Princeton University Press.

Human Rights Watch. 2001. Nigeria: Jos, a city torn apart. Human Rights Watch 13(9A): $1-25$.

Huraoult, J. 1998. Land crisis on the Mambila Plateau of Nigeria, West Africa. Journal of Biogeography 25(2): 285-299.

Krause, J. 2011. A deadly cycle: Ethno-religious conflict in Jos, Nigeria. Geneva: Small Arms Survey.

Little, PD. 1989. The dairy commodity system of the Kismayo region, Somalia: Rural and urban dimensions. Binghamton: Institute for Development Anthropology.

Mahama, Cl, M Desquesnes, ML Dia, B Losson, R De Deken, N Speybroeck, and S Geerts. 2005. A longitudinal epidemiological survey of bovine trypanosomosis and its vectors in the White Volta river basin of Northern Ghana. Veterinary Parasitology 128: 201-208.

Majekodunmi, AO, A Fajinmi, C Dongkum, K Picozzi, MV Thrusfield, and SC Welburn. 2013a. A longitudinal survey of trypanosomiasis on the previously tsetse-free Jos Plateau, Nigeria: Prevalence, distribution and risk factors. Parasites \& Vectors 6: 239.

Majekodunmi, AO, A Fajinmi, C Dongkum, K Picozzi, E MacLeod, MV Thrusfield, AP Shaw, and SC Welburn. 2013b. Social factors affecting seasonal variation in bovine trypanosomiasis on the Jos Plateau, Nigeria. Parasites \& Vectors 6: 293.

Michael, BJ. 1987. Milk production and sales by the Hawazma (Baggara) of Sudan: Implications for gender roles. Research in Social Anthropology 9: 105-141.

Moritz, M. 2006. Changing contexts and dynamics of farmer-herder conflicts across West Africa. Canadian Journal of African Studies 40(1): 1-40.

Moritz, M. 2010. Understanding herder-farmer conflicts in West Africa: Outline of an analytical approach. Human Organization 69(2): 138-148.

Niamir, M. 1982. Report on animal husbandry among the Ngok Dinka of the Sudan. Cambridge: Rural Development Studies, Harvard Institute for International Development.

Ocaido, M, CP Otim, NM Okuna, J Erume, C Ssekitto, RZO Wafula, D Kakaire, J Walubengo, and J Monrad. 2005. Socio-economic and livestock disease survey of agro-pastoral communities in Serere County. Uganda: Livestock Research for Rural Development Soroti District. 17: 1-15.
Otchere, E. 1983. The productivity of White Fulani (Bunaji) cattle in pastoralist herds in the Kaduna Plains of Nigeria. Nigeria: International Livestock Centre for Africa.

Oyedipe, EO, V Buvanendran, and LO Eduvie. 1982. Some factors affecting the reproductive performance of White Fulani (Bunaji) cattle. Tropical Agriculture 59: $231-234$

Pullan, NB. 1979. Productivity of White Fulani cattle on the Jos Plateau, Nigeria. I: Herd structures and reproductive performance. Tropical Animal Health and Production 11: 231-238.

Pullan, NB. 1980. Productivity of White Fulani cattle on the Jos Plateau, Nigeria. II: Nutritional factors. Tropical Animal Health and Production 12: 17-24.

Pullan, NB, and RJ Grindle. 1980. Productivity of White Fulani cattle on the Jos Plateau, Nigeria. IV: Economic factors. Tropical Animal Health and Production 12: $161-170$

Rass, N. 2006. Policies and strategies to address the vulnerability of pastoralists in sub-Saharan Africa. Rome: Pro-Poor Livestock Policy Initiative, Food and Agriculture Organisation of the United Nations.

Roderick, S, P Stevenson, and J Ndungu. 1998. The production parameters influencing the composition and structure of pastoral cattle herds in a semi-arid area of Kenya. Animal Science 66: 585-594.

Tonah, S. 2000. State policies, local prejudices and the cattle rustling along the Ghana - Burkina Faso border. Africa 70(4): 551-567.

Wagenaar, KT, A Diallo, and AR Sayers. 1986. Productivity of transhumant Fulani cattle in the inner Niger Delta of Mali. ILCA Research Report No. 13. Addis Ababa: International Livestock Centre for Africa.

Wheat, JD, and J Broadhurst. 1968. An analysis of data on Bunaji Cattle at Birnin Kudu and Kabomo, N. Nigeria. Samaru Miscellaneous Paper No. 25. Zaria: Ahmadu Bello University.

Wheat, JD, PN de Leeuw, and BA Koch. 1972. Bunaji cattle at the Shika Research Station, North Central State, Nigeria. Zaria: Ahmadu Bello University.

Wilson, RT. 1986. Livestock production in central Mali: Long-term studies on cattle and small ruminants in the agropastoral system. ILCA Research Report No. 14. Addis Ababa: International Livestock Centre for Africa.

\section{doi:10.1186/s13570-014-0020-7}

Cite this article as: Majekodunmi et al:: Pastoral livelihoods of the Fulani on the Jos Plateau of Nigeria. Pastoralism: Research, Policy and Practice 2014 4:20.

\section{Submit your manuscript to a SpringerOpen ${ }^{\odot}$ journal and benefit from:}

- Convenient online submission

$\checkmark$ Rigorous peer review

- Immediate publication on acceptance

- Open access: articles freely available online

- High visibility within the field

- Retaining the copyright to your article

Submit your next manuscript at $>$ springeropen.com 